\title{
Vertical ground reaction force analysis during gait with unstable shoes
}

\author{
Análise da força vertical de reação do solo \\ durante a marcha com calçado instável
}

\author{
Giulia Pereiraa $^{[a]}$, Aluísio Otavio Vargas Avila ${ }^{[b]}$, Rudnei Palhano ${ }^{[b] *}$ \\ [a] Universidade Feevale, Novo Hamburgo, RS, Brazil \\ [b] Instituto Brasileiro de Tecnologia do Couro, Calçado e Artefatos (IBTeC), Novo Hamburgo, RS, Brazil
}

\begin{abstract}
Introduction: Footwear is no longer just an accessory but also a protection for the musculoskeletal system, and its most important characteristic is comfort. Objectives: This study aims to identify and to analyze the vertical ground reaction force in barefoot women and women with unstable shoes. Methodology: Five women aged $25 \pm 4$ years old and mass of $50 \pm 7 \mathrm{~kg}$ participated in this study. An AMTI force plate was used for data acquisition. The 10 trials for each situation were considered valid where the subject approached the platform with the right foot and at the speed of $4 \mathrm{~km} / \mathrm{h} \pm 5 \%$. The instable shoe of this study is used in the practice of physical activity. Results: The results showed that the first peak force was higher for the footwear situation, about $5 \%$ and significant differences between the barefoot and footwear situation. This significant difference was in the first and second peaks force and in the time of the second peak. Conclusion: The values showed that the footwear absorbs approximately $45 \%$ of the impact during gait.
\end{abstract}

Keywords: Unstable shoes. Impact force. Gait. Biomechanics. Chiropractic.

* GP: grad., e-mail: giuliabp@gmail.com AOVA: PhD, e-mail: biomecanica@ibtec.org.br RP: PhD, e-mail: rudnei@ibtec.org.br 


\section{Resumo}

Introdução: $O$ calçado deixou de ser acessório e tornou-se uma proteção para o sistema musculoesquelético, tendo como principal objetivo o conforto. Objetivo: O presente estudo tem como objetivo verificar e analisar a componente vertical de reação do solo em mulheres descalço e com calçado instável. Metodologia: Participaram deste estudo cinco mulheres com idade de $25 \pm 4$ anos e massa de $50 \pm 7 \mathrm{~kg}$. Para a aquisição dos dados foi utilizado plataforma AMTI. Foram consideradas válidas 10 tentativas de o sujeito abordar a plataforma com o pé direito e na velocidade de $4 \mathrm{~km} / \mathrm{h} \pm 5 \%$. 0 calçado instável deste estudo foi utilizado na prática de atividade física. Resultados: Os resultados apresentaram que o primeiro pico de força foi maior para a situação calçado, cerca de 5\%, e diferenças significativas entre a situação descalço e com calçado para o primeiro pico de força, segundo pico de força e tempo do segundo pico de força. Conclusão: Verificou-se que o calçado absorve aproximadamente $45 \%$ do impacto durante a marcha.

Palavras-chave: Calçados instáveis. Impacto. Marcha. Biomecânica. Quiropraxia.

\section{Introduction}

There have been several studies in search of a better understanding about the characteristics of the shoes and the consequences of their use for the locomotor system as well as the search of technological innovation which encircles the processes, development and production. The footwear industry is constantly looking for technological innovation in order to add value to the product and supply the deficiency in competitiveness on the domestic/foreign market. Therefore, companies come up with several models (designs) of shoes with a particular function/ purpose. However, often the shoes with a particular function do not have the performance for which they were designed. With these shoes, whether performance or casual shoes, there is a necessity to verify the execution in order to analyze the performance. In this sense, one can relate that the footwear used by individuals often does not have the necessary comfort for the development of daily activities (1).

According to Melo et al. (2), depending on certain factors, such as footwear is designed/produced by the manufacturer will affect positively or negatively the health and performance of the individual. An example can be cited by Hennig (3), that the highheeled shoes can cause damage to the spine, knee problems and even the shortening of hamstring and gastrocnemius muscles. Besides that, the author states that with the shortening of the leg muscles posterior, there is an increase of incidence of sprains and fractures at the ankle and foot. As for Freitas et al. (4), the use of inappropriate footwear can cause alterations in the musculoskeletal system, in which the following stand out: postural changes, which provide certain structural adaptations of the skeletal system; predisposition for muscle injuries; pains in the spine due to the decrease of the normal curve of the lumbar lordosis; pelvic tilt and development of degenerative processes. Great part of the shoes is considered stable, for example, walking shoes, running, etc. However, the use of a stable shoe might contribute to the reduction of the performance of a muscle group over time (5). Unstable shoes can be used for various therapeutic purposes, such as back pain, osteoporosis, arthritis, flat feet, heel spurs, hallux valgus, circulatory problems (mellitus diabetic), injury rehabilitation in the lower limbs, among others $(6,7)$. Miller et al. (7), compared two groups and some wore the unstable footwear Kangoo Jumps and others conventional shoes during the running and walking. The subjects underwent a 12 -week training period and the group that wore conventional shoes showed incidence of injury when compared with the group that wore Kangoo Jumps shoes. Related injuries were: pain in the tibialis anterior muscle, plantar fasciitis, ankle sprains, among others. In contrast, $58 \%$ of subjects who wore Kangoo Jumps presented pain in the plantar arch and 30\% presented superficial lesions in the skin tissue, such as blisters.

In the shoe structure, for example, the sole has a determining function to absorb the impact and return 
energy during movement. The unstable footwear used in this study has the sole geometrically similar to Masai Barefoot Technology (MBT) shoes, i.e., with rounded sole in the anterior-posterior direction providing instability during movement. The main objective of the material used in the manufacture of soles is the reduction of impact forces, considering that, during the impact the collision between the foot and the ground generates a shock wave that is transmitted to the musculoskeletal system. This shock wave has a magnitude between 5 and 15 times the acceleration of gravity in the lower limbs and is attenuated to 1 up to 3 times the acceleration of gravity in the head area $(8,9)$. The impact forces and shock waves are influenced by the subject's weight, speed, kinematic arrival of the foot to the ground, the footwear and surface properties, among others $(10,11)$. Some studies analyzed various methods and materials for determining the shock absorption during gait (10, $11,12)$ however, studies have been found $(10,11,13$, $14,15,16,17,18,19)$ which used the rate of loading, first peak force and temporal variables of the vertical ground reaction force to compare/analyze shoes or parameters during gait. Currently, there are several studies focused on minimalist shoes, leaving aside the unstable shoes. In this sense, the study of Amadio and Duarte (9) analyzed that the incidence of lower limb injuries has remained very low in populations that do not have the habit of using any type of footwear, and also, comparing to places where populations who wear footwear coexist, a higher incidence of injury can be seen. The authors' hypothesis was that there would be adjustments related to the activities carried out without the use of footwear, which would provide shock absorption and protection against injury associated with running, wherein the stiffness of the foot/ shoe would explain the high incidence of injuries in the lower limbs (20).

In Brazil, the concern with the quality of footwear resulted in the creation of standards to evaluate the comfort of the shoe in 2002 (21). The set of norms, whose responsible body is the Brazilian Association of Technical Standards (ABNT), consist of tests and parameters associated with biomechanics which allow us to differentiate the footwear and quantify its comfort. Some important parameters for the comfort of the footwear can now be evaluated according to Brazilian standards, for example the absorption of impact by vertical ground reaction force during gait, plantar pressure distribution, pronation angle, among others. These assessments have been applied to all types of footwear, for example, casual, sports footwear, also covering safety shoes and women's high heeled shoes. Nevertheless, there is a lot to study due to modifications and improvements of such norms, which tend to specialize according to the type of footwear, its characteristics and specific purposes. Currently at the shoes store there are different kinds of shoes and models with different features. A wide variety of materials to absorb the impact has been incorporated into the damping system in running and walking shoes, these include elastic and viscoelastic polymeric foams, air, gases, gels, fluids, composites and molded springs, among others (22). Furthermore, it is possible to check that there are few studies focused on unstable shoes. However, a large number of practitioners of physical activity with the unstable footwear used in this study was observed, in which walking, running and jump stand out.

Therefore, the importance to search for biomechanical knowledge, development, production and evaluation of unstable footwear is evident. Thus, the need for this study, which aims to analyze the behavior of the vertical ground reaction force on women in barefoot conditions and with unstable footwear during gait.

\section{Methodology}

The study included five female subjects who were recruited by non-probabilistic process of the intentional kind, and all subjects had not previously worn the unstable Kangoo Jumps shoes. The participants were aged (25 \pm 4 ) years; Mass (50 \pm 8$) \mathrm{kg}$. Individuals who had a history of injury or neuro-musculoskeletal changes were excluded and/or submitted to orthopedic/neurological procedures in the last two years. Shortly after the statement of the protocol, subjects signed the informed consent approved by the ethics committee of Feevale under No. 252,964. The procedures for data acquisition were: research subjects walked on a walkway of 10 meters, which was secured on the ground to the force platform (model 0R67-2000 - AMTI, the sampling frequency was $2000 \mathrm{~Hz}$ ). Speed control was used indirectly, i.e., the time of each acquisition was measured through photocells placed 3 meters apart. The 10 trials were considered valid for every situation in which the subject approached the platform with the right foot at the 
speed of $4 \mathrm{~km} / \mathrm{h}$ ( $5 \%$ ) (23). The situations for data acquisition were: barefoot and with unstable Kangoo Jumps shoes, the situations for data acquisition was randomized. The unstable footwear has the sole with a rounded shape, as shown in Figure 1. According to the manufacturer, the Kangoo Jumps shoe absorbs $80 \%$ of the impact (24). Prior to the data acquisition the subjects went through an adjustment period with unstable footwear of approximately 5 minutes.

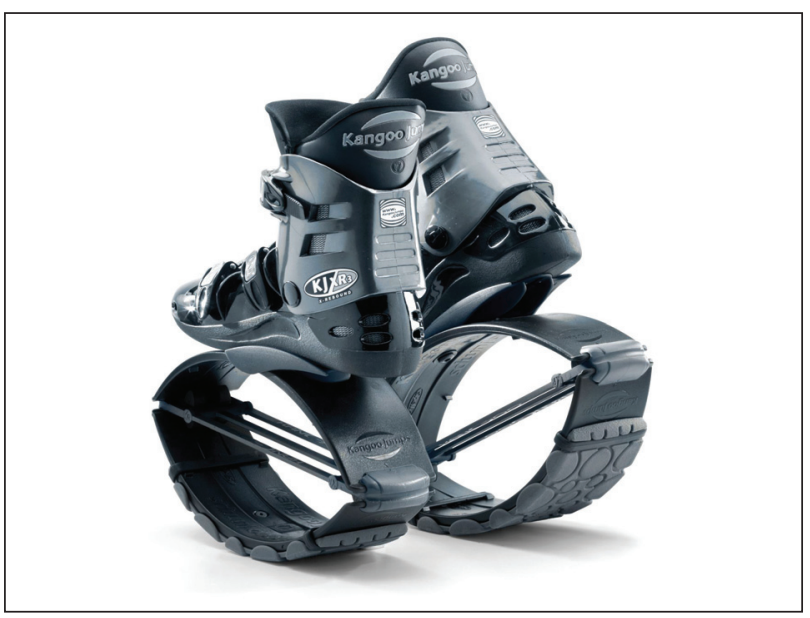

Figure 1 - Unstable footwear used in the study Source: Kangoo Jumps (24).

The variables used in this study were: First Peak Force (FPF); time of first peak force (tFPF); Second Peak Force (SPF); time of the Second Peak Force (tSFP) and rate of loading of the vertical ground reaction force during walking. The rate of loading was determined by the first derivative of the vertical ground reaction force comprised within the range of 10 to $20 \%$ of FPF $(10,23)$. Data processing was by Matlab $^{\text {m }}$ codes wherein the raw data were filtered with a low pass filter $\left(4^{\text {th }}\right.$ order Butterworth filter, cutoff frequency of $70 \mathrm{~Hz}$ ) (10). To determine the differences between barefoot and the use of footwear situations among the variables, it was determined with Student's t-test with significance level of 5\% by SPSS ${ }^{\mathrm{m}}$ software.

\section{Result and discussion}

Using Figure 2, it was found that FPF was higher for the footwear situation compared to barefoot, approximately $5 \%$ higher. Statistical comparison showed that there is a statistical difference between barefoot situation compared to the unstable footwear ( $p=0.049)$. In the study by Santos (25) the results meet this study's results, however, the work by Clarke et al. (26) which examined footwear with compressed air bubble found higher values (1.99 BW $\pm 0.21 \mathrm{BW}$ ) than this study. It is believed that the first peak force value of Kangoo Jumps shoes may be related to the stiffness of the spring secured to Kangoo Jumps midsole when compared with the barefoot situation in which the foot presents the fat pad as one of the damping systems during gait.

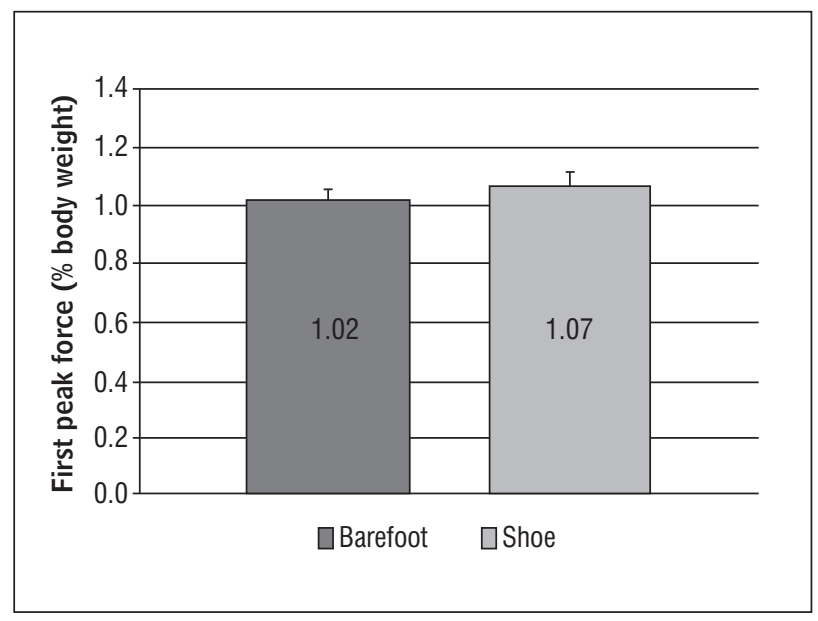

Figure 2 - First peak force for barefoot situation and with footwear

Another very similar study (19) compared the kinetic variables of 8 female subjects for situations: barefoot, sneakers and sandals in self-selected speed. The authors found for the first peak force significant and superior values (barefoot (1.09 BW $\pm 0.06 \mathrm{BW}$ ) Sandal (1.18 BW $\pm 0.07 \mathrm{BW}$ )), Sneaker (1.14 BW \pm $0.05 \mathrm{BW}$ ) when compared with the results found in this study. It is believed that this difference in numbers may be related to the speed of the subject, since the kinetic variables are influenced by the speed during locomotion $(27,28)$. Also in this sense, the study by Newton et al. (29) which compared Kangoo Jumps shoes with conventional shoes, the authors found similar values of force peak between the Kangoo Jumps (2.85 BW $\pm 0.37 \mathrm{BW}$ ) and sneakers (2.62 BW \pm $0.21 \mathrm{BW}$ ) while jogging.

In temporal comparison between situations (Figure 3), it was observed that the situation with footwear presented a longer period compared to 
barefoot, approximately $16 \%$ longer for the footwear. It is also believed that in the situation with footwear being longer may be related to the spring deflection in the central region of the sole which has the function of absorbing the impact force during the first phase of the gait and returning it during the second phase of the gait (propulsion phase). As for statistical comparison, there was no significant difference in the time of the first peak force between situations.

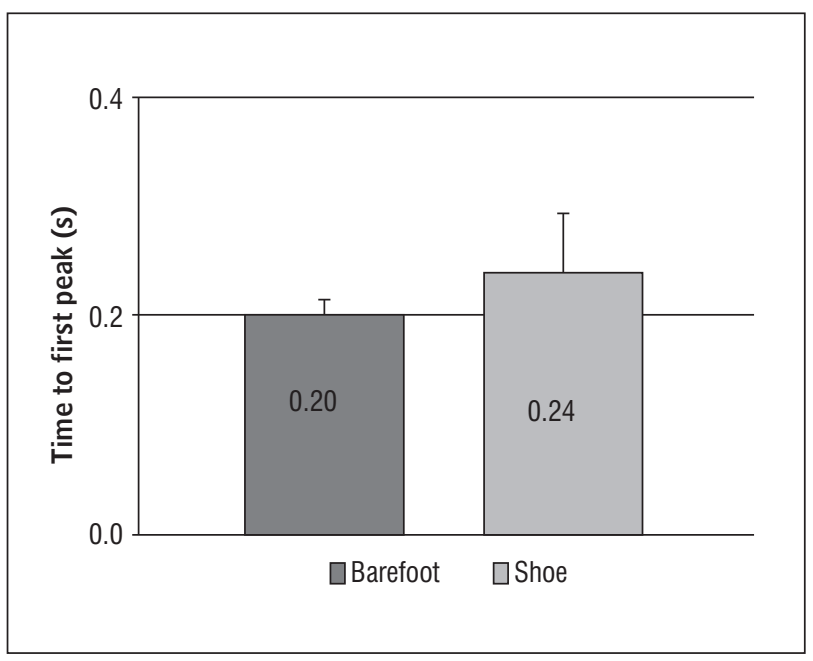

Figure 3 - Time of first peak force for barefoot and footwear situation

Some studies examined the temporal variables, such as the works by Demura et al. (16) and Myers et al. (30) which analyzed two shoes with different geometries in soles (one with flat soles and another with bends in the heel and toes area). The authors found significant differences in the temporal variables, for example in cadence, speed during gait, time of the stance phase and balance, among others. On the other hand, De Witt et al. (31) evaluated running shoes with different hardnesses in midsole and, found greater magnitude of the first vertical peak force on the footwear with greater hardness in comparison to the lower hardness shoes and the time to reach the first peak was higher for the softer footwear. It is believed that the results of Figure 3 for the footwear situation may be related to the modification of kinematic motion, i.e., there is a change in the pattern of motion when the subject uses unstable footwear (6). Whereas Newton et al. (29) found the time of peak force about $25 \%$ higher for footwear Kangoo Jumps compared to conventional shoes.
During the propulsion phase during gait as shown in Figure 4, a higher peak in barefoot situation was observed when compared to footwear, about $6 \%$ higher, respectively. This difference may be related to the return energy of the sole since the deformation of the spring occurred during the impact absorption stage and it is believed that this energy will be returned during the propulsion phase (11). As for statistical comparison, the statistical difference between the situations for the second peak force $(p=0.033)$ was observed. Sacco et al. (19), also found a significant difference for the second force peak between the barefoot and with shoes situations (barefoot (1.06 $\mathrm{BW} \pm 0.06 \mathrm{BW}$ ) sandal (1.09 BW $\pm 0.07 \mathrm{BW})$ ) sneakers (1.07 BW \pm 0.05 BW) $(p=0.0162)$. Stolt et al. (32) also found lower value in the second force peak in the barefoot condition (1.10 BW $\pm 0.05 \mathrm{BW}$ ) compared to the situation with footwear (1.11 BW $\pm 0.04 \mathrm{BW})$. However, in this study it was possible to observe that the barefoot situation was higher when compared to the footwear situation (Figure 4), diverging from the values found by Sacco et al. (19) and Stolt et al. (32).

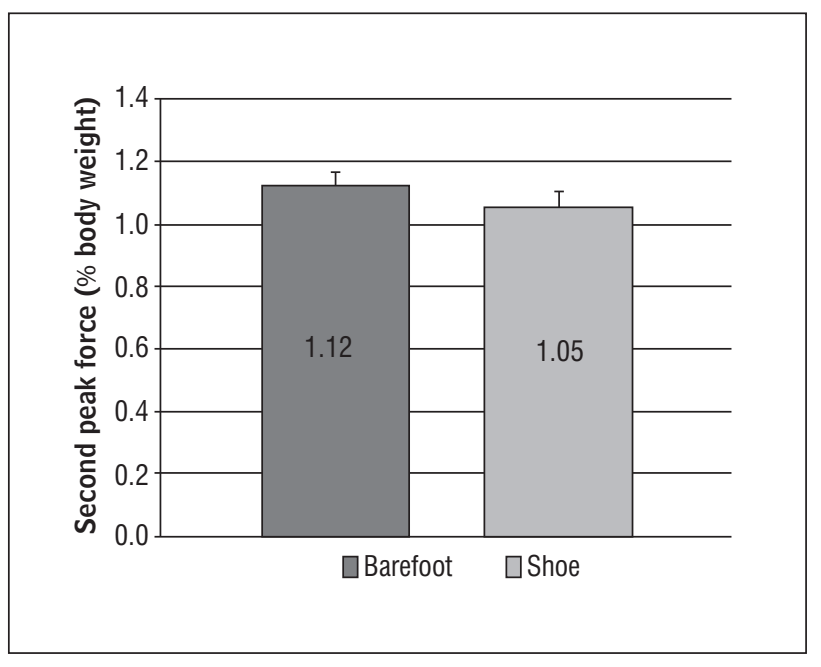

Figure 4 - Second peak force for barefoot and footwear situations

In relation to the time values of the second peak force during movement (Figure 5), there was a higher temporal variation comprehended between the shoe contact on the ground to the maximum propulsion peak, higher for the footwear situation, i.e., a delay of approximately $11 \%$ occurs, higher when subjects wore the footwear during the phase of propulsion. In statistical comparison of the second peak force, 
a significant difference between the situations was found ( $p=0.035)$. This higher time value of the footwear in comparison to barefoot situation may be attributed to the characteristic of the sole, i.e., an elastic deformation of the spring occurs during the gait. Newton et al. (29) also observed a longer time in the contact phase in subjects who wore the footwear Kangoo Jumps compared to conventional shoes.

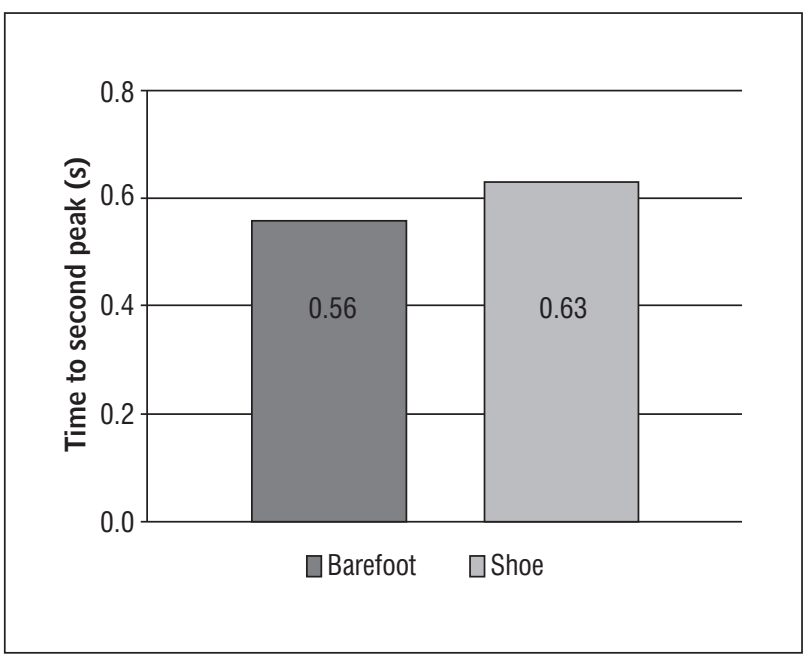

Figure 5 - Time of second peak force for barefoot and footwear use situation

Looking at the rate of loading that is first derived comprehended between 10 to $20 \%$ of first peak force during gait. As expected, the highest rate of loading, i.e., the highest slope of the curve occurred for barefoot situation (46.71 BW/s $\pm 9.65 \mathrm{BW} / \mathrm{s}$ ) compared to footwear (25.79 BW/s $\pm 17.94 \mathrm{BW} / \mathrm{s})$. Equating situations, it was observed that footwear absorbed $45 \%$ of the impact force during movement, deviating from that presented by the manufacturer. However, the manufacturer does not say how the impact absorption rate was determined. Even so, in a similar study Newton et al. (29), found through the thrust between the contact of the foot on the ground up to $50 \mathrm{~ms}$ of the stance phase approximately $47 \%$ lower than the impact of the Kangoo Jumps shoes, related to conventional shoe during jogging, meeting the results of this study. Crowell et al. (33) through visual feedback led the study participants, during the running, to reduce the impact. In the rate of loading values, it was observed that the values found in this study are close to those by Santos (25) for footwear situation in which two types of women's shoes were assessed. Sacco et al. (19), on the other hand, did not find significant differences in the situations (barefoot, sandals and sneakers) in the rate of loading. According to Palhano et al. (13) and Nigg (11), the impact force is an important variable for the etiology of injuries in athletes. According to the authors, the physical/mechanical properties of the design and the sole influence the absorption of impact force, i.e., the rate of loading.

\section{Conclusion}

Through this study, it can be concluded that in the comparisons between the barefoot and unstable footwear use situations, there is a significant difference between the situations for the first peak force, second peak force and the variation in time of the second peak force. In the first force peak variable there is an increase of $5 \%$ when subjects wore the Kangoo Jumps footwear. It was also observed that the shoes presented low impact absorption during gait, about $45 \%$. It was also observed that there is a lack in literature on the subject and the continuation of this study with other variables to obtain reliable results is necessary.

\section{Acknowledgments}

We thank IBTeC Laboratory for providing the equipment to carry out this work, and also the employees who dedicated themselves to assist me in data acquisition.

\section{References}

1. Donelan JM, Kram R, Kuo AD. A simultaneous positive and negative external mechanical work in human walking. J Biomech. 2002;35(1):117-24.

2. Melo MF, Campos GT, Bonfim TR. Influência do uso do calçado de salto alto no arco plantar e na extensibilidade do músculo tríceps sural. Anais do 11. Congresso Brasileiro de Biomecânica; 2005, João Pessoa, PB, Brasil.

3. Hennig EM. The evolution and biomechanics of the human foot - applied research for footwear. Braz J Biomech. 2003;4(1):7-14. 
4. Freitas SM, Wieczorek SA, Marchetti PH, Duarte M. Age-related changes in human postural control of prolonged standing. Gait Posture. 2005;22(4):322-30.

5. Jackman RW, Kandarian SC. The molecular basis of skeletal muscle atrophy. Am J Physiol Cell Physiol. 2004;287(4):C834-43.

6. Romkes J, Rudmann C, Brunner R. Changes in gait and EMG when walking with the Masai Barefoot Technique. Clin Biomech. 2006;21(1):75-81.

7. Miller N. Taunton JE, Fraser S, Rhodes E, Zumbo B. Kangoo Jumps: an innovative training device. B C Med J. 2003;45(9):444-8.

8. Shorten MR. The energetics of running and running shoes. J Biomech. 1993;26(Suppl 1):41-51.

9. Amadio CA, Duarte M. Fundamentos biomecânicos para a análise do movimento humano. São Paulo: Laboratório de Biomecânica - EEFUSP; 1996.

10. Palhano R. Análise mecânica e biomecânica de solados para calçados [tese]. Porto Alegre: Universidade Federal do Rio Grande do Sul; 2013.

11. Nigg BM. Biomechanics of sport shoes. Calgary: University of Calgary; 2010.

12. Lieberman DE, Venkadesan M, Weber WA, Daoud AI, D'Andrea S, Davis IS, et al. Foot strike patterns and collision forces in habitually barefoot versus shod runners. Nature. 2010;463(7280):531-5.

13. Palhano R, Balbinot G, Varga AP, Zaro MA, Faquin A, Strohaecker TR. Análise do impacto em calçados durante a marcha. In: Anais do 23. Congresso Brasileiro de Engenharia Biomédica; 2012, Porto de Galinhas, PE, Brasil.

14. Balbinot G, Schuch CP, Palhano R, Zaro MA. Sistema de footswitch de baixo custo para mensuração dos parâmetros espaço temporais da marcha. In: Anais do 23. Congresso Brasileiro de Engenharia Biomédica, 2012, Porto de Galinhas, PE, Brasil.

15. Bernardes E, Balbinot G, Palhano R, Faquin A, Zaro MA. Análise do índice de amortecimento durante a caminhada com calçados minimalistas. Revista Tecnicouro. 2012;34:96-106.

16. Demura T, Demura S, Yamaji S, Yamada T, Kitabayashi T. Gait characteristics when walking with rounded soft sole shoes. Foot. 2012;22(1):18-23.
17. Faquin A. 0 calçado esportivo destinado à pratica de futsal: avaliações mecânicas, biomecânicas e de percepção [tese]. São Paulo: Universidade de São Paulo, 2012.

18. Santos DM, Melo SIL, Carneiro LC, Andrade MC. Características da marcha de idosos considerando a atividade física e o sexo. Fisioter Mov. 2008;21(4):137-48.

19. Sacco ICN, Tessutti VD, Aliberti S, Hamamoto NA, Gomes DR, Costa MSX. Força reação do solo durante a marcha com uso de tênis e sandália plataforma. Fisioter Mov. 2007;20(3):55-62.

20. Ly QH, Alaqui A, Erlicher A, Baly L. Towards a footwear design tool: influence of shoe midsole properties and ground stiffness on the impact force during running. J Biomech. 2010;43(2):310-7.

21. Associação Brasileira de Normas Técnicas. NBR 14834-14840: Normas para avaliação de calcados. Rio de Janeiro: ABNT, 2002.

22. Shorten MR. Running shoe design: protection and performance. In: Pedoe DT, editor. Marathon medicine. London: Royal Society of Medicine; 2000. p. 159-69.

23. Associação Brasileira de Normas Técnicas. NBR 14838: determinação do índice de amortecimento do calçado. Rio de Janeiro: ABNT, 2011.

24. KangooJumps.com [internet]. 2013 [cited $2013 \mathrm{Nov}$ 20]. Available from: http://www.kangoojumps.com.br

25. Santos AMC. Análise cinética da marcha de mulheres em três condições: descalça e utilizando calçados de salto baixo e salto alto [dissertação]. Florianópolis: Universidade Estadual de Santa Catarina, 2007.

26. Clarke TE, Frederick EC, Cooper LB. Effects of shoe cushioning upon ground reaction forces in running. Int J Sports Med. 1983;4(4):247-51.

27. White SC, Tucker CA, Brangaccio JA, Lin HY. Relation of vertical ground reaction forces to walking speeds. Gait Posture. 1996;4(2):206.

28. Bruneira CAV, Amadio A. Análise da forca de reação do solo para o andar e correr com adultos normais do sexo masculino durante a fase de apoio. In: Anais do 5. Congresso Brasileiro de Biomecânica; 1993 dez 1-3; Santa Maria, RS, Brasil. São Paulo: Sociedade Brasileira de Biomecânica; 1993. p. 19-24. 
29. Newton RU, Humphries BJ, Ward IB. Reducing ground impact forces during jogging: an evaluation of shoes with spring. 1995 [cited 2015 Sept 15]. Available from: http://kangoojumps.com/downloads/references/Ref-lis.pdf

30. Myers KA, Long JT, Klein JP, Wertsch J, Janisse DJ, Harris GF. Biomechanical implications of the negative heel rocker sole shoes: gait kinematics and kinetics. Gait Posture. 2006;24(3):323-30.

31. de Witt B, DE Clercq D, Lenoir M. The effect of varying midsole hardness on impact forces and foot motion during foot contact in running. J Appl Biomech. 1995;11(4):395-406.

32. Stolt LROG, Esteves AC, Leite RM, Melo SIL. Características dinâmicas e espaço temporais da marcha e meninas descalças e calçadas. In: Anais do 11. Congresso Brasileiro de Biomecânica; 2005 jun 19-22, João Pessoa, PB, Brasil. João Pessoa: UFPB; 2005.
33. Crowell HP, Milner CE, Hamill J, Davis IS. Reducing impact loading during running with the use of realtime visual feedback. J Orthop Sports Phys Ther. 2010;40(4):206-13.

Received: 12/16/2014

Recebido: $16 / 12 / 2014$

Approved: 04/06/2015

Aprovado: 06/04/2015 